Original Research Paper

\title{
Chemical Composition, Texture and Sensory Evaluation of Yogurts Supplemented with Amaranth Flour
}

\author{
${ }^{1}$ Alma Aytkozhayevna Shunekeyeva, ${ }^{2}$ Mariam Alimardanova and ${ }^{3}$ Majorov Alexandr Albertovich \\ ${ }^{1}$ Shokan Ualikhanov Kokshetau University, Kokshetau, Kazakhstan \\ ${ }^{2}$ Almaty Technological University, Almaty, Republic of Kazakhstan \\ ${ }^{3}$ Federal Altai Scientific Center of Agro Biotechnologies, Barnaul, Russian Federation
}

\author{
Article history \\ Received: 25-02-2021 \\ Revised: 19-04-2021 \\ Accepted: 26-04-2021 \\ Corresponding Author: \\ Alma Aytkozhayevna \\ Shunekeyeva \\ Shokan Ualikhanov Kokshetau \\ University, Kokshetau, \\ Kazakhstan \\ Email: a.shunekeyeva@kgu.kz
}

\begin{abstract}
This study aimed to assess the effect of adding non-roasted and roasted amaranth flour to yogurt at a dose of $5 \mathrm{~g}$ per $100 \mathrm{~mL}$ on the approximate composition, storage stability, texture and sensory evaluation of yogurt. Yogurt without supplementation was used as control. The products were evaluated for moisture, carbohydrate, protein, fat, ash and mineral content. In order to assess the rheological properties, the following indicators of $\mathrm{PH}$, acidity and syneresis of yogurts were measured after 1, 7, 15 days of storage. To analyse and evaluate such indicators of yogurts as color, texture, taste, aroma and overall acceptability, ten faculty members used a hedonistic scale. The results showed that samples with supplements were significantly higher in protein, carbohydrate and fat. Thus, the study arrived that yogurt from goat's milk could be used. However, adding more than $5 \mathrm{~g} 100 \mathrm{~mL}$ non-roasted amaranth flour had undesirable effect on gel stability (increasing of total acidity and syneresis). Still, adding roasted amaranth flour increased sensory properties: Improved aroma and gave a nutty taste to the finished product.
\end{abstract}

Keywords: Chemical Composition, Texture, Sensory Evaluation, Yogurt Amaranth Flour

\section{Introduction}

It is now well established from various studies that amaranth (lat. Amaranthaceae) is a genus of flowering plants of the amaranth family, a cereal crop domesticated since ancient times (Czaplicki et al., 2012). In the past few years, there has been renewed interest in grain amaranth as healthy and nutritive source. The reason of that, if compared to such basic grains as wheat and rice, amaranth holds more protein with a well-balanced amino acid composition, vitamins, minerals and phytochemicals (Alvarez-Jubete et al., 2010; Collar et al., 2014; Curti et al., 2017; Singh and Punia, 2020).

Many authors (Sun et al., 1999; Xu and Sun, 2001; Aguilar et al., 2013; Singh and Punia, 2020) state that Amaranth species, being widely distributed in places as diverse as Africa, India, China, North and Central America and the South American Andes, are likely to have different domestication and origin centers. By all the species, Amaranthus caudatus, Amaranthus hypochondriacus and Amaranthus cruentus are mainly grown for seed production (Capriles et al., 2008; Repo-Carrasco-Valencia et al., 2009). According to (Barrio and Añón, 2010) these species consider as pseudocereals, with a high content of seed protein, lysine content and versatile usage. It has been documented that amaranth seeds are benefited for food and feed use (Lyon and Becker, 1987; Zhang et al., 2019). Despite the fact that in amaranth seeds the oil content is only $5-8 \%$, amaranth seed oil is gaining increasing attention due to its high content of unsaturated fatty acids and a large number of biologically active compounds, especially squalene (2.4-8.0\%) (Cicero et al., 2018; Zhang et al., 2019). Thus, several studies (Hlinková et al., 2013; Zhang et al., 2019) have shown that "amaranth seed generally contains $12.6-18.0 \%$ of protein, $5-8 \%$ fat, $60-$ $65 \%$ saccharides and $3-5 \%$ crude fibre". The amaranth grain can be used in different types: Toasted, popped, milled into flour. Therefore, it could be consumed as such or be included in other products as crackers, cookies, etc. (Rastogi and Shukla, 2013; Shinde et al., 2020). Previous research has confirmed that amaranth seeds are helpful for patients with coronary heart disease and hypertension (Martirosyan et al., 2007; Zhang et al., 2019).

Goat's milk with increased content of bioactive components constituted a valuable raw material for the production of Ayran based on the process of lactic milk fermentation. The beneficial health properties of Ayran are linked to the fatty acid profile of goat milk 
(Shunekeyeva et al., 2021). Compared to regular milk, fermented milk is more nutritious and has a higher content of proteins, vitamins and minerals (Hashemi et al., 2015; Curti et al., 2017).

Fermented milk is a high-consumed foods in the world. For the consumer such characteristics as general properties of the yogurt, the acidity level, the formation of aromas, appearance, color and texture (sensory profile) are important to make a choice (Sfakianakis and Tzia, 2014; Curti et al., 2017). The present work aims to determine texture, composition, stability during storage and sensory evaluation of yogurts supplemented with non-roasted and roasted amaranth flour. The data presented here are of great importance for the development of yogurts from amaranth flour.

\section{Materials and Methods}

\section{Amaranth Grain Processing}

Experimental samples of amaranth seeds were taken from Shokan Ualikhanov Kokshetau University, department of Plant Growing and Soil Science (Variety "Cherginsky", Amaranthus fruentus), then were manually sorted and rinsed under tap water for $30 \mathrm{~min}$ (Chemeda and Bussa, 2018; Shinde et al., 2020). The washed grains were dried for $5-6 \mathrm{~h}$ at $55 \pm 5^{\circ} \mathrm{C}$, then packed in plastic bags and stored at room temperature $20-25^{\circ} \mathrm{C}$ (Sushil and Suneeta, 2008; Sindhu et al., 2019; Shinde et al., 2020). To obtain unroasted amaranth flour, the seeds were ground with a coffee grinder and then sieved in $250 \mathrm{~mm}$. Roasted flour was obtained in oven (Gorenje, Slovenia) at $127 \pm 1^{\circ} \mathrm{C}$ for 5-6 min or till golden brown color and cooled to $20-25^{\circ} \mathrm{C}$ (Shinde et al., 2020). The Fig. 1 depicts the preparation of flour from roasted amaranth grain (Shinde et al., 2020).

\section{Yogurts Formulation}

Goat's milk was obtained from the breeding farm "Zerenda" (Akmola region, Kazhymukan village). The goat milk was obtained from the goats of the Saanen (Shunekeyeva et al., 2021; Shunekeyeva, 2021). The preparation of amaranth flour supplemented yogurts were as follows: 5 g.per $100 \mathrm{~mL}$ sugar and different concentrations of non-roasted amaranth flour (hereafter, F1: 5 g.per $100 \mathrm{~mL}$ ) and roasted amaranth flour (hereafter, F2: 5 g.per $100 \mathrm{~mL}$ ) were added to pasteurized goat milk, mixed during $2 \mathrm{~min}$, then heated at $44^{\circ} \mathrm{C}$ and injected the amount recommended by the manufacturer which is 0.02 g.per 100 $\mathrm{mL}$ of Streptococcus thermophilus and Lactobacillus delbrueckii subsp. bulgaricus YO-MIX 88350 DCU from Danisco France SAS, Paris, France (commercial lyophilized culture). The samples were added $0.20 \mathrm{~mL}$ of vanilla per 100 $\mathrm{mL}$, packed in sterile plastic cups and incubated in an oven at $43-45^{\circ} \mathrm{C}$ until a $\mathrm{pH}$ of 4.6 was reached. At the end of the fermentation, the yogurts were cooled in a refrigerator to $5^{\circ} \mathrm{C}$ and stored for 15 days. As a control treatment was used an yogurt without additives.

\section{Proximate Composition}

Total solids, protein, fat, ash, sensory evaluation and titratable acidity were determined in accordance with the methods described by the standard methods:

- $\quad$ GOST 23327-98 (1998) "Milk and dairy products. Method for measuring the mass fraction of total nitrogen by Kjeldahl and determining the mass fraction of protein"

- GOST 32940-2014 (2015) “Goat raw milk. Technical conditions"

- GOST 3624-92 (1994) "Milk and dairy products. Titrimetric methods for the determination of acidity"

- GOST 3625-84 (1985) "Milk and dairy products. Methods for determining the density"

- GOST 3626-73 (1974) "Milk and dairy products. Methods for determining moisture and dry matter"

- GOST 5867-90 (1991) "Milk and dairy products. Methods for determining fat"

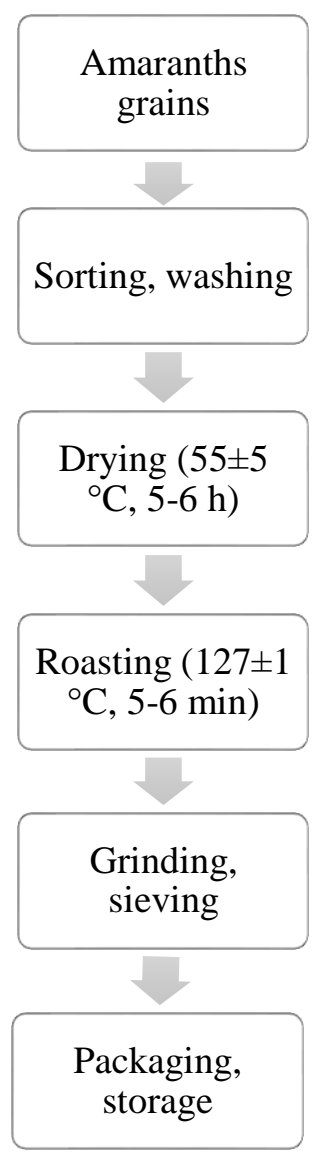

Fig. 1: Flow chart for the preparation of roasted amaranth grain flour 


\section{Yogurts Stability During Refrigerated Storage}

During storage at $5^{\circ} \mathrm{C}$ at $1 \mathrm{st}, 7 \mathrm{th}, 15$ th days the $\mathrm{pH}$ were recorded using a digital $\mathrm{pH}$-meter (Russia) and total acidity by titration of yogurt samples ("Milk and dairy products. Titrimetric methods for the determination of acidity", 2009). Contingent viscosity measurements were taken at $20^{\circ} \mathrm{C}$ with a simple method: By-product leaking time from a pipette (100 $\mathrm{mL})$ with outlet diameter $(5 \mathrm{~mm})$. The time of the clot leaking (at the end of fermentation) should be at least 20 sec. Whey was collected from a yogurt cup and the results were presented as a percentage of the original yogurt weight (GOST 31981-2013, 2013). The average value of 3 measurements was taken.

\section{Yogurts Instrumental Texture}

After one day of storage, a texture profile analysis was carried out by employing a Reokon-2 texture analyzer (Russia). The yogurts were pressed in the original containers using a flat indenter and an acrylic cylindrical probe at a depth of $2 \mathrm{~mm}$ at a compression rate of 7.6 $\mathrm{mm} / \mathrm{sec}$. (Shunekeyeva et al., 2020).

\section{Sensory Evaluation}

The yogurts with the addition of amaranth flour were evaluated for acceptability by a faculty members (men: 4; women: 6), recruited from among the teachers of the Polytechnical Faculty, Shokan Ualikhanov Kokshetau University, Kazakhstan. Panelists were asked to taste the yogurts without being told which ingredient was added. $30 \mathrm{~mL}$ of each of the two experimental samples and control sample were introduced simultaneously in disposable plastic cups. The panelists were asked to rate their preferences for taste, aroma, color, texture and overall acceptability. All samples were served at $5 \pm 1^{\circ} \mathrm{C}$ and filtered tap water was used to clean the mouth between samples. The rating scale was nine-point, ranging from " like extremely" to " dislike extremely ".

All panelists gave written informed consent to participate in the study (Hekmat and Reid, 2006).

\section{Statistical Analysis}

One-way Analysis Of Variances (ANOVA) was used to test for differences between the proximate composition of the yogurt samples. A chi-squared test used to determine the magnitude of differences in scores assigned on a hedonic scale to sensory attributes and a p-value $<0.05$ was assented as significant. Data are presented as mean \pm standard deviation. Statistical analyses were conducted using statistical program Statistica (StatSoft, Russia).

\section{Results}

\section{Proximate Composition}

Chemical composition: Moisture (9.7\%), dry mass for carbohydrates $(59.5 \%)$, ashes $(1.85 \%)$, fats $(4.5 \%)$ and proteins $(9.8 \%)$ of amaranth flour (Alekseeva, 2013).

Chemical composition: Ca (0.9-1.0g), P (0.5-0.6\%) and proteins (14.1\%) of amaranth flour (Derkanosova et al., 2016).

The proximate composition of non-roasted amaranth flour corresponded to data from different sources (Alekseeva, 2013; Derkanosova et al., 2016) for moisture, dry mass for carbohydrates, ashes, fats and proteins. Table 1 shows physical and chemical indicators of amaranth flour, $\mathrm{Ca}, \mathrm{Na}$ and $\mathrm{P}$ contents in $\mathrm{mg} 100 \mathrm{~mL}$.

It was possible to formulate yogurts supplemented with amaranth flour at $5 \mathrm{~g} 100 \mathrm{~mL}$. According to the results, there were significant differences in carbohydrate, protein and fat content between the control and the supplemented yogurts (Table 2). The decrease in moisture content was observed as an increase in flour concentration, although ash (except F2) and minerals (mainly $\mathrm{Na}$ and $\mathrm{P}$ ) did not differ significantly between samples (Table 2). The lowest calcium content was found in F2.

\section{Stability of Yogurts During Refrigerated Storage}

A higher increase in total acidity values was observed in the samples with a larger amount of amaranth flour (F1) than in the control and yogurt with the addition of fried amaranth flour (Fig. 2). The $\mathrm{pH}$ values of all products dropped during storage (Fig. 2) and the largest decrease was observed in F1 as a consequence of the increase in total acidity (Fig. 2). Syneresis was noticed in yogurt supplemented with non-roasted amaranth flour and control sample and percentages of whey separation corresponded to 0.41 and $0.37 \%$ at $15 \mathrm{~d}$ of storage respectively.

\section{Instrumental Texture of Yogurts}

Samples of finished products with amaranth flour were probed using by Reokon-2 (Fig. 3). The steeper the graph rises, the stronger the clot formed (Shunekeyeva et al., 2020; 2021). According to the data received, the strongest yogurts clot is obtained by adding amaranth flour (F1, F2).

\section{Sensory Evaluation}

In terms of sensory score, F2 performed better on all sensory features and was significantly different from F1 and the control sample (Table 3). However, there were minor differences between F1 and F2 (Table 3). The mean score for overall acceptability in F2 was 7.15 which corresponds to "like the product moderately". 
Alma Aytkozhayevna Shunekeyeva et al. / American Journal of Animal and Veterinary Sciences 2021, 16 (2): 136.143 DOI: 10.3844/ajavsp.2021.136.143

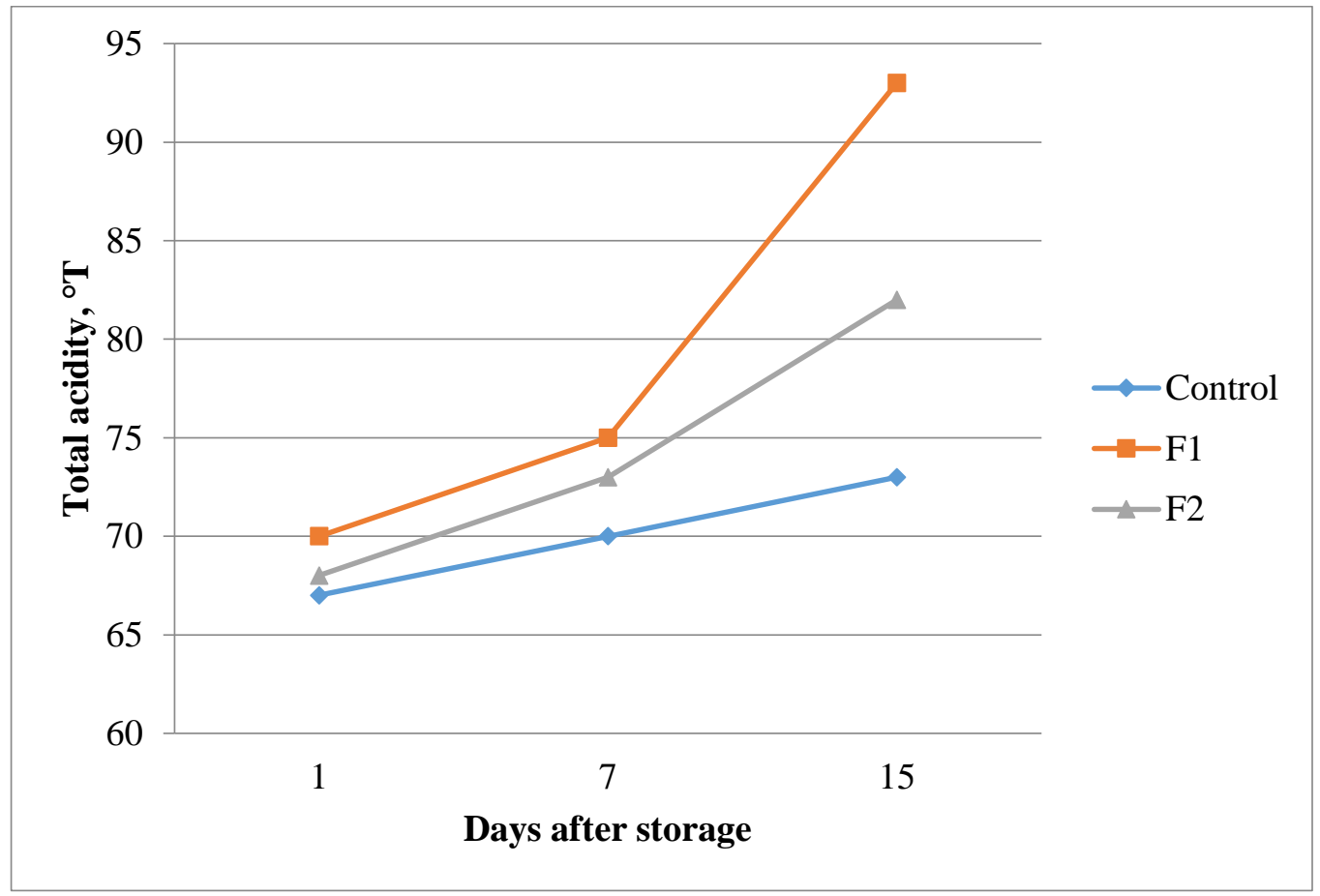

(a)

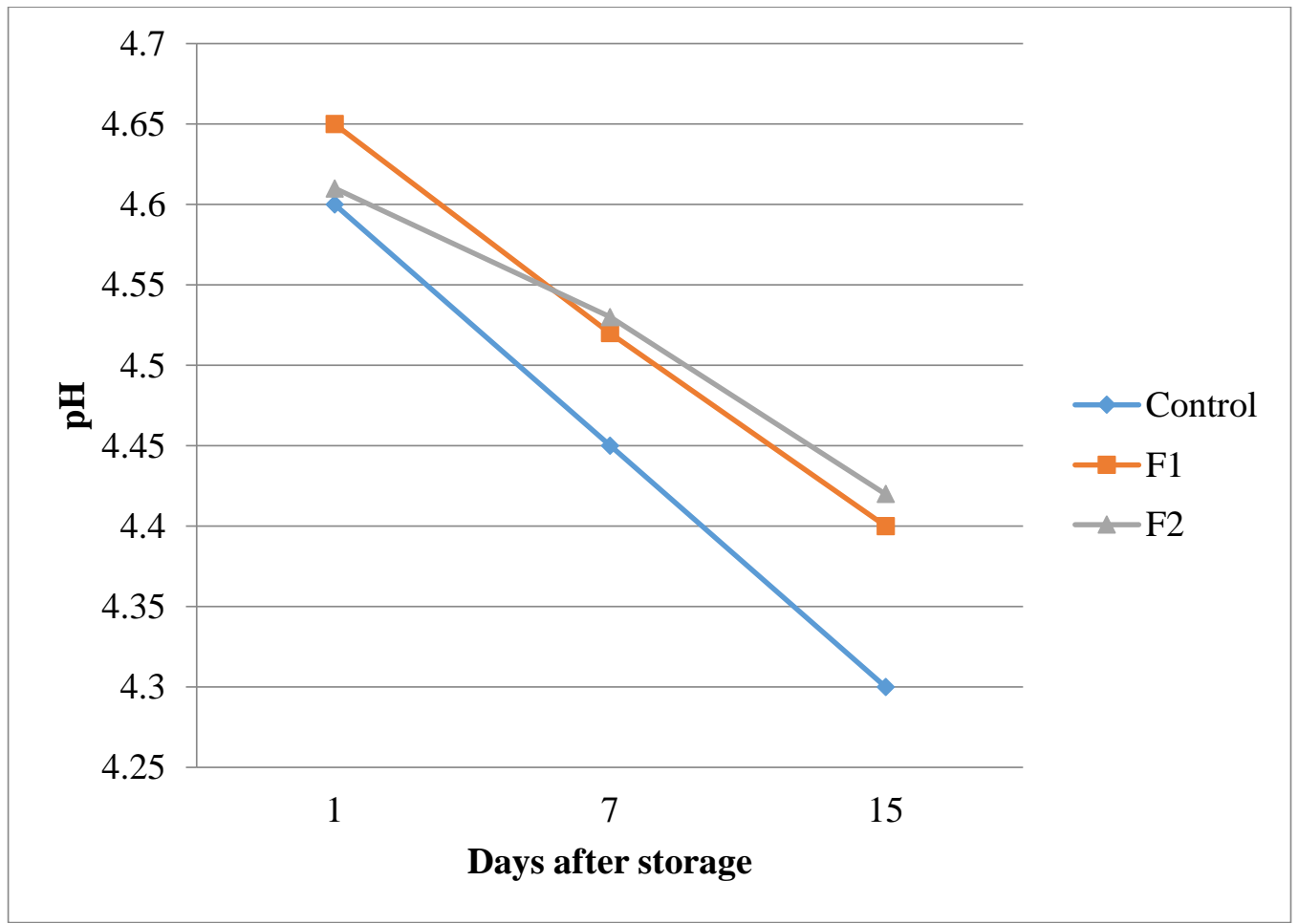

(b)

Fig. 2: Total acidity values (a) and pH values (b) of supplemented yogurts. Yogurts supplemented with amaranth flour (non-roasted and roasted) 


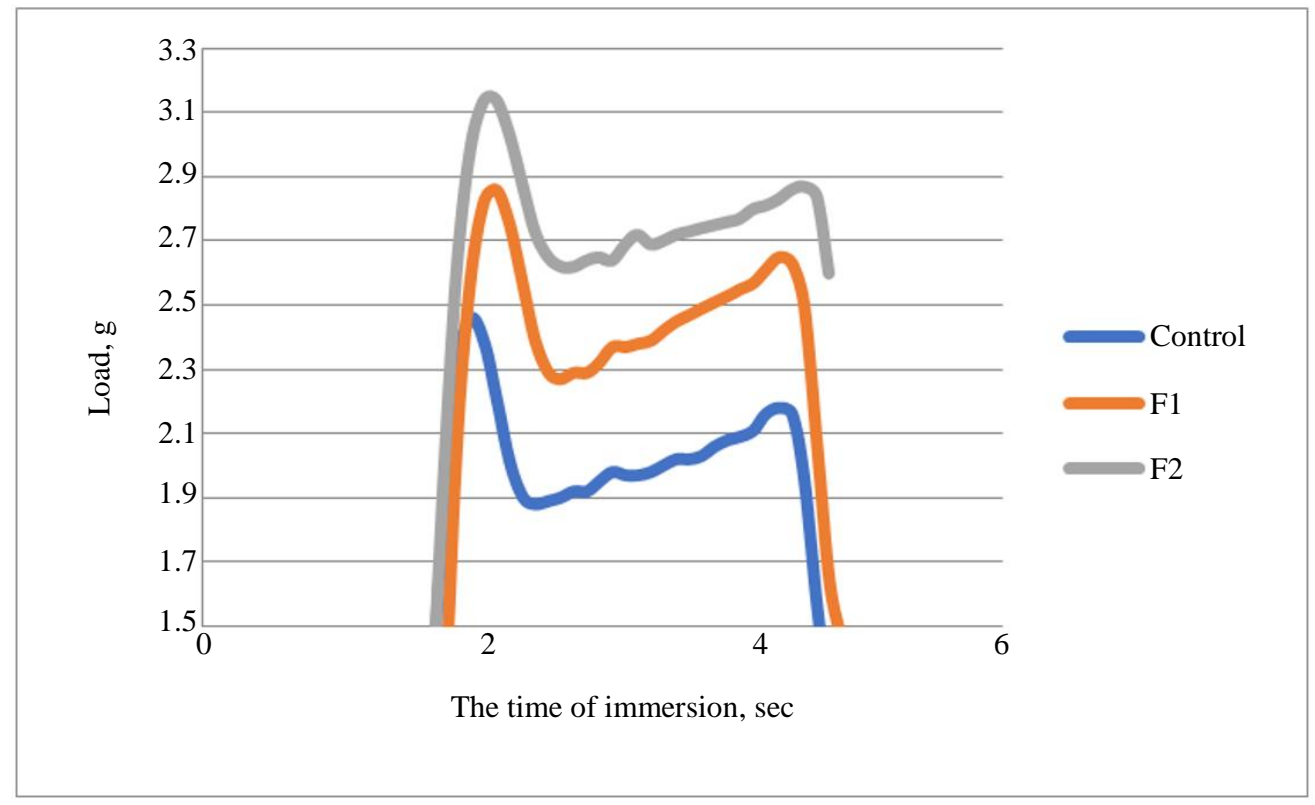

Fig. 3: Structural and mechanical properties of yogurts samples

Table 1: Physical and chemical indicators of non-roasted and roasted amaranth flour

\begin{tabular}{|c|c|c|c|c|c|c|c|c|}
\hline Traits & Moisture & Carbohydrates & Proteins & Fats & Ashes & $\mathrm{Ca}$ & $\mathrm{Na}$ & $P$ \\
\hline Non-roasted amaranth flour & $9.7 \pm 0.1$ & $60 \pm 0.46$ & $6.5 \pm 0.1$ & $3.3 \pm 0.6$ & $1.8-1.9$ & $87.9 \pm 10$ & $71.1 \pm 10$ & $287.7 \pm 10$ \\
\hline Roasted amaranth flour & $7.9 \pm 0.3$ & $79 \pm 1.1$ & $9.76 \pm 0.57$ & $1.6 \pm 0.6$ & $1.7 \pm 0.22$ & $19.7 \pm 10$ & $16.2 \pm 10$ & $128.4 \pm 10$ \\
\hline
\end{tabular}

Table 2: The Proximate composition of the control and yogurts with the addition of amaranth flour

\begin{tabular}{|c|c|c|c|}
\hline \multirow[b]{2}{*}{ Traits } & \multicolumn{3}{|l|}{ Yogurts } \\
\hline & Control (SD) & $\mathrm{F} 1(\mathrm{SD})$ & $\mathrm{F} 2(\mathrm{SD})$ \\
\hline Moisture & $79.23(0.05)$ & $82(1.1)$ & $85.1(0.8)$ \\
\hline Carbohydrates & $11.7(0.1)$ & $7.3(0.02)$ & $7.41(0.12)$ \\
\hline Proteins & $4.24(0.02)$ & $5.3(0.2)$ & $5.1(0.02)$ \\
\hline Fats & $3.41(0.11)$ & $3.24(0.23)$ & $3.3(0.01)$ \\
\hline Ashes & $0.87(0.03)$ & $0.7(0.01)$ & $0.84(0.02)$ \\
\hline $\mathrm{Ca}$ & $187(8.7)$ & $165(11.1)$ & $112.5(3.17)$ \\
\hline $\mathrm{Na}$ & $82.52(0.37)$ & $82.17(1.4)$ & $78.17(2.2)$ \\
\hline $\mathrm{P}$ & $92.2(5.43)$ & $59.4(1.2)$ & $58(0.9)$ \\
\hline
\end{tabular}

$\mathrm{p}<0.05$. Moisture, carbohydrates, proteins, fats and ashes are expressed in $\mathrm{g} 100 \mathrm{~mL}$, whereas $\mathrm{Ca}, \mathrm{Na}$ and $\mathrm{P}$ in $\mathrm{mg} 100 \mathrm{~mL}$

Table 3: Sensory quality of yogurts of non-roasted and roasted amaranth flour and control sample

\begin{tabular}{llllll}
\hline Attributes & Overall acceptability (SD) & Colour (SD) & Texture (SD) & Flavour (SD) & Aroma (SD) \\
\hline Control & $6.37(0.29)$ & $6.60(0.51)$ & $6.50(0.5)$ & $6.5(0.71)$ & $5.8(0.78)$ \\
F1 & $6.85(0.27)$ & $6.7(0.48)$ & $7.0(0.4)$ & $7.1(0.32)$ & $6.6(0.52)$ \\
F2 & $7.15(0.47)$ & $7.4(0.69)$ & $7.2(0.63)$ & $6.7(0.83)$ & $7.3(0.82)$ \\
\hline
\end{tabular}

(F1, F2) Yogurts supplemented with 5 g $100 \mathrm{~mL}$ amaranth flour (non-roasted and roasted). $\mathrm{p}<0.05$

\section{Discussion}

Analysis of non-roasted and roasted amaranth flour showed that the flour were rich in protein $(6.5,9.76 \%$ respectively), carbohydrates $(60.0,79.0 \%$ respectively) and fats $(3.3,1.6 \%$ respectively). The present study values for protein are comparable with the published data (Alekseeva, 2013; Derkanosova et al., 2016).
Nutty flavour generated in the amaranth grains when subjected to the roasting process (Shinde et al., 2020).

Yogurt samples analysed met the required standards for physicochemical composition and microbiological indicators. The determined moisture, carbohydrates, proteins, fats and ashes content is shown in Table 2 and showed slight differences between samples. The 
determined fat content is shown in Table 2 and displays slight differences between samples. The control sample had the highest fat content, whereas F1, F2 had the lowest fat content among the samples $(\mathrm{P}<0.05)$. There is possible explanation for this result.

As shown in Table 2 the protein and fat content of amaranth flour influenced the content of yogurts: An increase in yogurt samples fat content was associated with a decrease in moisture content.

The results of moisture content are presented in Table 2. The moisture content of the control sample was the lowest among the yogurt samples and the F2 content was the highest among all the samples $(\mathrm{P}<0.05)$. The amaranth flour-supplemented yogurts were found to have higher moisture content than the control sample $(\mathrm{P}<0.05)$. The result on $\mathrm{pH}$ and total acidity values of yogurts are summarized in Fig. 2. According to data research (Tamime and Deeth, 1980; Kim et al., 2020) the most suitable $\mathrm{pH}$ of yogurt is in the range of 3.7 to 4.7 . The yogurt samples' $\mathrm{pH}$ levels ranged from 4.65 to 4.36 and $\mathrm{pH}$ was decreased with the addition of amaranth flour. The $\mathrm{pH}$ of the amaranth flour - supplemented yogurts was slightly higher than that of control groups $(\mathrm{P}<0.05)$. The $\mathrm{pH}$ of $\mathrm{F} 1$ and F2 were slightly decreased after 15 days storage.

From the results, sensory characteristics of yogurts with non-roasted and roasted amaranth flour has slight differences. It has been suggested that the sensory properties of food are strongly related to consumer preferences and determine product acceptability; this phenomenon can help optimize the recipe (Kim et al., 2020). The results of the sensory evaluation of yogurt samples are shown in Table 3. The sensory attributes of yogurt were divided into the following categories: Appearance and color, taste, texture, aroma and general acceptability. The appearance is perceived visually and the surface is evaluated by smoothness, shape and texture. The F2 received the best scores in all categories evaluated among the samples. Draws a distinction between flavor, which is strongly related to preferences regarding food and quality properties.

In the present study, adding roasted amaranth flour to yogurts showed increasing sensory properties: Improved aroma and a nutty taste to the finish $\$$ Ed product (F2).

\section{Conclusion}

It was possible to formulate yogurts with two different types amaranth flour. Although nutritional composition showed improvements, the addition of amaranth flour had an undesirable effect on consistency, increased syneresis and overall acidity were found during storage. The overall acceptability decreases when adding the non-roasted amaranth flour in a product. The main weakness of this study was the paucity of size of our panel (10 people). With a small sample size, caution must be applied, as the findings might not be transferable to show objective data. In spite of its limitations, the study certainly adds to our understanding of the production of yogurts with roasted amaranth flour is preferable. Further research is needed to investigate the effects of amaranth flour and apply it to various foods as a supplement to enhance overall quality parameters of fermented foods.

\section{Acknowledgement}

The author's would like to offer particular thanks to Uzbergenova Saule for support.

\section{Author's Contributions}

Alma Shunekeyeva: Contributed to the design and implementation of the research, to the analysis of the results and to the writing of the manuscript.

Mariam Alimardanova: Coordinated the mous work.

Alexandr Majorov: Gave valuable suggestions during this research work's planning and development.

\section{Ethics}

This article is original and contains unpublished material. The corresponding author confirms that the author's had read and approved the manuscript and no ethical issues involved.

\section{References}

Aguilar, E. G., Peiretti, E. G., Uñates, M. A., Marchevsky, E. J., Escudero, N. L., \& Camiña, J. M. (2013). Amaranth seed varieties. A chemometric approach. Journal of Food Measurement and Characterization, $7(4)$, 199-206. https://link.springer.com/article/10.1007/s11694013-9156-1

Alekseeva, E. I. (2013). Nauchnye osnovy ispol'zovanija muki amarantovoj jekstrudirovannoj $\mathrm{v}$ pishhevyh produktah (Scientific bases of using amaranth extruded flour in food products) (In Russian) /Proceedings of BSU, 8: 39-42.

Alvarez-Jubete, L., Wijngaard, H., Arendt, E. K., \& Gallagher, E. (2010). Polyphenol composition and in vitro antioxidant activity of amaranth, quinoa buckwheat and wheat as affected by sprouting and baking. Food Chemistry, 119(2), 770-778. https://doi.org/10.1016/j.foodchem.2009.07.032

Barrio, D. A., \& Añón, M. C. (2010). Potential antitumor properties of a protein isolate obtained from the seeds of Amaranthus mantegazzianus. European Journal of Nutrition, $\quad 49(2), \quad 73-82$. https://link.springer.com/article/10.1007\%2Fs00394 -009-0051-9 
Capriles, V. D., Coelho, K. D., Guerra-Matias, A. C., \& Arêas, J. A. (2008). Effects of processing methods on amaranth starch digestibility and predicted glycemic index. Journal of Food Science, 73(7), H160-H164. https://doi.org/10.1111/j.1750-3841.2008.00869.x

Chemeda, A. S., \& Bussa, N. F. (2018). Effect of Processing Methods on Nutritional and Antinutritional Value of Amaranth Grain; and Potential Future Application of Amaranth Grain in Injera Making. International Journal of Fermented Foods, $7(1)$, 11-20. https://search.proquest.com/openview/7bb5e644e $2 \mathrm{a}$ 0ff465fed5d2de7dab009/1?pq-

origsite $=$ gscholar $\& \mathrm{cbl}=2032159$

Cicero, N., Albergamo, A., Salvo, A., Bua, G. D., Bartolomeo, G., Mangano, V.,... \& Dugo, G. (2018). Chemical characterization of a variety of coldpressed gourmet oils available on the Brazilian market. Food Research International, 109, 517-525. https://doi.org/10.1016/j.foodres.2018.04.064

Collar, C., Jiménez, T., Conte, P., \& Fadda, C. (2014). Impact of ancient cereals, pseudocereals and legumes on starch hydrolysis and antiradical activity of technologically viable blended breads. Carbohydrate Polymers, 113, 149-158. http://dx.doi.org/10.1016/j.carbpol.2014.07.020

Curti, C. A., Vidal, P. M., Curti, R. N., \& Ramón, A. N. (2017). Chemical characterization, texture and consumer acceptability of yogurts supplemented with quinoa flour. Food Science and Technology, 37(4), 627-631.

https://www.scielo.br/scielo.php?script=sci_arttext $\&$ pid=S0101-20612017000400627

Czaplicki, S., Ogrodowska, D., Zadernowski, R., \& Derewiaka, D. (2012). Characteristics of biologically-active substances of amaranth oil obtained by various techniques. Polish Journal of Food and Nutrition Sciences, 62(4): 235-239.

Derkanosova, N. M., Ponomareva, I. N., Zolotareva, N. I., \& Kuralesina, V. N. (2016). Izuchenie hlebopekarnogo potenciala cel'nosmolotoj muki iz amaranta. Bulletin of the Voronezh state Agrarian University. (In Russian: Изучение хлебопекарного потенциала цельносмолотой муки из амаранта. Вестник Воронежского государственного аграрного университета). 3 (50): 175-182. http://doi.org/10.17238/issn2071-2243.2016.3.175

GOST 23327-98. (1998). Milk and dairy products. Method for measuring the mass fraction of total nitrogen by Kjeldahl and determining the mass fraction of protein: Official publication. Official publication. Standard in form. http://docs.cntd.ru/document/1200021650

GOST 31981-2013. (2013). Yogurts. General specifications: Official publication. IPK Publishing house of standards. Standardinform. http://docs.cntd.ru/document/1200107778
GOST 32940-2014. (2015). Goat raw milk. Technical conditions: Official publication. Standardinform. http://docs.cntd.ru/document/1200115755

GOST 3624-92. (1994). Milk and dairy products. Titrimetric methods for the determination of acidity: Ed. official. IPK Publishing house of standards, Standardinform. http://docs.cntd.ru/document/gost3624-92

GOST 3625-84. (1985). Milk and dairy products. Methods for determining the density: official publication. Standardinform. http://docs.cntd.ru/document/1200021585

GOST 3626-73. (1974). Milk and dairy products. Methods for determining moisture and dry matter: Official publication. Standardinform. http://docs.cntd.ru/document/1200021586

GOST 5867-90. (1991). Milk and dairy products. Methods for determining fat: Official publication. IPK Publishing house of standards: Standardinform. http://docs.cntd.ru/document/1200021592

Hashemi, G., Eskandari, M. H., Mesbahi, G., \& Hanifpour, M. A. (2015). Scientific and technical aspects of yogurt fortification: a review. Food Science and Human Wellness, 4(1), 1-8. http://doi.org/10.1016/j.fshw.2015.03.002.

Hekmat, S. \& Reid, G. (2006). Sensory properties of yogurt is comparable to standard yogurt. Nutrition Research - NUTR RES. 26, 163-166. http://doi.org/10.1016/j.nutres.2006.04.004.

Hlinková, A., Bednárová, A., Havrlentová, M., Šupová, J., \& Čičová, I. (2013). Evaluation of fatty acid composition among selected amaranth grains grown in two consecutive years. Biologia, 68(4), 641-650. https://www.degruyter.com/document/doi/10.2478/s 11756-013-0190-6/html

Kim, S. Y., Hyeonbin, O., Lee, P., \& Kim, Y. S. (2020). The quality characteristics, antioxidant activity and sensory evaluation of reduced-fat yogurt and nonfat yogurt supplemented with basil seed gum as a fat substitute. Journal of Dairy Science, 103(2), 1324-1336. http://doi.org/10.3168/jds.2019-17117

Lyon, C. K., \& Becker, R. (1987). Extraction and refining of oil from amaranth seed. Journal of the American Oil Chemists' Society, 64(2), 233-236. https://link.springer.com/article/10.1007/BF02542008

Martirosyan, D. M., Miroshnichenko, L. A., Kulakova, S. N., Pogojeva, A. V., \& Zoloedov, V. I. (2007). Amaranth oil application for coronary heart disease and hypertension. Lipids in Health and Disease, 6(1), $1-12$.

https://lipidworld.biomedcentral.com/articles/10.118 6/1476-511X-6-1

Rastogi, A., \& Shukla, S. (2013). Amaranth: a new millennium crop of nutraceutical values. Critical Reviews in Food Science and Nutrition, 53(2), 109-125. https://www.tandfonline.com/doi/abs/10.1080/1040 8398.2010.517876 
Repo-Carrasco-Valencia, R., Peña, J., Kallio, H., \& Salminen, S. (2009). Dietary fiber and other functional components in two varieties of crude and extruded kiwicha (Amaranthus caudatus). Journal of Cereal Science, 49(2), 219-224. https://doi.org/10.1016/j.jcs.2008.10.003

Sfakianakis, P., \& Tzia, C. (2014). Conventional and innovative processing of milk for yogurt manufacture; development of texture and flavor: a review. Foods, 3(1), 176-193. http://doi.org/10.3390/foods3010176

Shinde, N., Kartikeyan, S., Agrawal, A., Goel, B., Choudhary, K., \& Punita, K. (2020). Selection of suitable form of amaranth (Amaranthus cruentus) for development of amaranth incorporated composite fermented milk drink. International Journal of Chemical Studies, 8(2), 352-357. http://doi.org/10.22271/chemi.2020.v8.i2f.8793

Shunekeyeva, A. A. (2021). Influence of Starter Cultures' Type on the Microbiological, Rheological and Sensory Properties of Ayran Samples from Goat's Milk. OnLine Journal of Biological Sciences, 21(1), 154-160. https://doi.org/10.3844/ojbsci.2021.154.160

Shunekeyeva, A. A., Mayorov, A. A., \& Alimardanova, M. K. (2020). Opredelenie strukturno-mehanicheskih svojstv kislomolochnyh napitkov iz koz'ego moloka s napolniteljami (Determination of structural-mechanical properties of a fermented beverage made from goat's milk with fillers) (In Russian). Scientific Journal "Mechanics and Technologies", 3(69), 100-105. ISSN10: 2308-9865

Shunekeyeva, A. A., Alimardanova, M. K., \& Majorov, A. A. (2021). Fruit-berry fillers in the production of kazakh national fermented milk drinks. Series Chemistry and Technology, 139-146. http://doi.org/10.32014/2021.2518-1491.18.
Sindhu, R., Beniwal, S.K. and Devi, A. (2019) Effect of Grain Processing on Nutritional and PhysicoChemical, Functional and Pasting Properties of Amaranth and Quinoa Flours. Indian Journal of Traditional Knowledge (IJTK), 18, 500-507.

Singh, A., \& Punia, D. (2020). Characterization and Nutritive Values of Amaranth Seeds. Current Journal of Applied Science and Technology, 27-33. http://doi.org/10.9734/cjast/2020/v39i330511

Sun, M., Chen, H., \& Leung, F. C. (1999). Low-Cot DNA sequences for fingerprinting analysis of germplasm diversity and relationships in Amaranthus. Theoretical and Applied Genetics, 99(3-4), 464-472. https://link.springer.com/article/10.1007\%2Fs00122 0051258

Sushil, N., \& Suneeta, P. (2018). Amaranth - A Functional Food. Con Dai \& Vet Sci 1(3). CDVS.MS.ID.000112. http://doi.org/10.32474. CDVS.2018.01.000112.

Tamime, A. Y., \& Deeth, H. C. (1980). Yogurt: technology and biochemistry. Journal of Food Protection, 43(12), 939-977. http://doi.org/10.4315/0362-028X-43.12.939

$\mathrm{Xu}$, F., \& Sun, M. (2001). Comparative analysis of phylogenetic relationships of grain amaranths and their wild relatives (Amaranthus; Amaranthaceae) using internal transcribed spacer, amplified fragment length polymorphism and double-primer fluorescent intersimple sequence repeat markers. Molecular Phylogenetics and Evolution, 21(3), 372-387. https://doi.org/10.1006/mpev.2001.1016

Zhang, Z. S., Kang, Y. J., \& Che, L. (2019). Composition and thermal characteristics of seed oil obtained from Chinese amaranth. LWT, 111, 39-45. http://doi.org/10.1016/j.lwt.2019.05.007 